\title{
The Effect of Realistic Mathematics Education and Problem Based Learning Model on Mathematics Problem Solving Ability in Terms of Precondition Mathematics Abilities
}

\author{
Anderson L Palinussa ${ }^{1, *}$ T C Dias ${ }^{2}$ Darma A Ngilawajan ${ }^{3}$ \\ ${ }^{1,3}$ Department of Mathematics Education, Pattimura University \\ ${ }^{2}$ Sekolah Menengah Atas Negeri 14 Maluku Tengah \\ *Corresponding author. Email: palinussaandersonl@gmail.com
}

\begin{abstract}
The purpose of this study is to compare two treatments, namely the realistic mathematics education approach (RME) and problem-based learning (PBL) towards students' mathematical problem-solving abilities. To obtain complete information about the comparison of the two models, we also used the non-treatment group as the control class. This research approach is quantitative using quasi-experimental methods. The design of this study is a nonequivalent comparison group design involving 243 students of SMA Negeri 14 Maluku, Indonesia, in the 2019/2020 academic year. The results showed that there were differences in students' problem abilities with the high, medium, and low Precondition Mathematics Abilities (PMA) categories. There is an interaction effect between RME, PBL, and conventional learning models with PMA on students' mathematical problem abilities.
\end{abstract}

Keywords: Realistic Mathematics Education, Problem Based Learning, Precondition Mathematics Abilities.

\section{INTRODUCTION}

Current educational orientation is for students to acquire knowledge and competencies that meet the needs of modern society [1]-[4]. In line with that, mathematical problem-solving skills are needed to process, communicate, solve problems, and interpret mathematical information in various contexts [5]-[7]. Thus, mastery of mathematical problem-solving abilities has significant implications for students.

Students' mathematical solving abilities can be improved by using an appropriate learning model [8]. Related to that, learning that regulates students to work with open problems and uses real-world contexts can develop students' mathematical problem-solving abilities [1], [9]-[13]. Learning models that meet these suggestions are the realistic mathematics education approach (RME) and problem-based learning (PBL).

In the literature, it has been found that mathematics learning that is supported by the implementation of RME can improve students' mathematical problem understanding abilities [14], [15]. On the other hand, the implementation of PBL also has a significant positive effect on students' mathematical problem-solving abilities [16]-[18]. However, until now the two have not been compared. Meanwhile, educators need sufficient knowledge to choose which of the two is more effective for students' mathematical problem-solving abilities.

In an effort to fill the gap, this study was conducted to compare the effectiveness of realistic mathematics education (RME) and problem-based learning (PBL) approaches to students' mathematical problem-solving abilities. To obtain complete information about the comparison of the two, this study also uses a conventional learning model as a controller. In addition, Precondition Mathematics Abilities (PMA) is determined as a moderator variable which is alleged to affect the implementation of RME and PBL on students' mathematical problem-solving abilities. This study will contribute to the literature on the importance of organizing classes by considering PMA. 


\section{METHOD}

\subsection{Research Design}

This study used a quasi-experimental method with a $3 \times 3$ design. This is because the study cannot control other variables that affect this study. The research design is presented in Table 1 below

Table 1 Design Research Model and PMA

\begin{tabular}{lccc}
\hline $\begin{array}{c}\text { Learning model } \\
(\mathrm{A})\end{array}$ & $\begin{array}{c}\text { High } \\
\left(\mathrm{B}_{1}\right)\end{array}$ & $\begin{array}{c}\text { Poderate } \\
\left(\mathrm{B}_{2}\right)\end{array}$ & $\begin{array}{c}\text { Low } \\
\left(\mathrm{B}_{3}\right)\end{array}$ \\
\hline RME $\left(\mathrm{A}_{1}\right)$ & $\mathrm{A}_{1} \mathrm{~B}_{1}$ & $\mathrm{~A}_{1} \mathrm{~B}_{2}$ & $\mathrm{~A}_{1} \mathrm{~B}_{3}$ \\
$\operatorname{PBL}\left(\mathrm{A}_{2}\right)$ & $\mathrm{A}_{2} \mathrm{~B}_{1}$ & $\mathrm{~A}_{2} \mathrm{~B}_{2}$ & $\mathrm{~A}_{2} \mathrm{~B}_{3}$ \\
Conventional & $\mathrm{A}_{3} \mathrm{~B}_{1}$ & $\mathrm{~A}_{3} \mathrm{~B}_{2}$ & $\mathrm{~A}_{3} \mathrm{~B}_{3}$ \\
$\left(\mathrm{~A}_{3}\right)$ & & & \\
\hline
\end{tabular}

Note:

A1B1 = Students' Mathematical Problem Solving Ability with High PMA category Using the RME Learning Model

A2B1 = Students' Mathematical Problem Solving Ability with High PMA category Using PBL Learning Model

A3B1 = Students' Mathematical Problem Solving Ability with High PMA category Using Conventional Learning Models

A1B2 = Students' Mathematical Problem Solving Ability with the PMA category Using the RME Learning Model

A2B2 = Students' Mathematical Problem Solving Ability with PMA category Using PBL Learning Model

A2B3 = Students' Mathematical Problem Solving Ability with PMA category Using Conventional Learning Models

A1C3 = Students' Mathematical Problem Solving Ability with the Low PMA category using the RME Learning Model

A1C3 = Students' Mathematical Problem Solving Ability with the Low PMA category Using the PBL Learning Model

A1C1 = Students' Mathematical Problem Solving Ability with Low PMA category Using Conventional Learning Models

The variables in this study were (1) the dependent variable, namely the ability to solve mathematical problems and self-efficacy; (2) the independent variable is the learning model and (3) the moderator variable is the initial mathematical ability. The moderator variable in this study PMA as a moderator can affect the relationship between mathematical problem-solving abilities and learning models

Table 2 Descriptive Analysis of Students by Class

\subsection{Participants}

The population in this study were all class $\mathrm{X}$ MIA students of SMA Negeri 14 Central Maluku for the 2019/2020 academic year, totalling four classes. The sample in this study was taken using a random sampling technique by paying attention to the average value of the previous Daily Test and the selected class X MIA 2, totalling 20 students as the experimental class 1 using the RME learning model, class X MIA 1 totalling 20 students as the experimental class. 2 which uses the PBL learning model, and class X MIA 3, totalling 21 students as a control class using conventional learning models

\subsection{Data Collection}

The data in this study were obtained from the test results of students' mathematical problem-solving abilities in the experimental and control classes on the three-variable linear equation system material given after the learning was completed. The mathematical problem solving ability test instrument used in this study measures four aspects, namely understanding the problem, making plans, implementing plans, looking back. Meanwhile, the students' PMA data were obtained from the pre-test given.

\section{RESULT AND DISCUSSION}

This research began by giving all students a preliminary test to determine the students' PMA, then given treatment to the three classes, namely learning activities using the RME learning model in the experimental class 1 , the PBL learning model in the Experiment class 2, and the control class given the conventional model. After the learning activities are given, a final test is given to measure students' mathematical problem-solving abilities. The results of the research were then processed using SPSS 19.0 and Microsoft Excel 2010 and the results are presented in Table 2 below:

\begin{tabular}{|c|c|c|c|c|c|c|c|c|c|c|c|c|c|c|}
\hline & \multicolumn{5}{|c|}{ Experiment Class 1} & \multicolumn{4}{|c|}{ Experiment Class 2} & \multicolumn{5}{|c|}{ Control Class } \\
\hline & Min & Max & $\bar{x}$ & SD & $\mathrm{N}$ & Min & Max & $\bar{x}$ & SD & $\mathrm{N}$ & Min & Max & $\overline{\boldsymbol{x}}$ & SD \\
\hline High & 22 & 34 & 28,5 & 2,73 & 4 & 18 & 26 & 24,61 & 2,91 & 2 & 19 & 25 & 23,0 & 2,87 \\
\hline Moderate & 12 & 18 & 16,7 & 2,98 & 7 & 11 & 17 & 14,92 & 2,88 & 7 & 8 & 16 & 12,52 & 2,63 \\
\hline Low & 6 & 10 & 7,8 & 2,91 & 9 & 5 & 10 & 7,34 & 2,93 & 12 & 5 & 8 & 6,32 & 2,81 \\
\hline Total & 0 & 17,67 & & 3,94 & 20 & & 15,63 & & 4,75 & 21 & & & & 4,01 \\
\hline
\end{tabular}

Based on Table 2, it is found that students with high PMA category are 6 people in the experimental class 1 and the average value is 28.5 . Then as many as 4 students in the experimental class 2 with an average value of 24.61 , and as many as 2 students in the dick class with an average value of 23.0. In PMA with a moderate category, 
in experimental class 1 there were 9 students with an average value of 16.70 , in the experiment 2 class there were 7 students with an average value of 14.92. For PMA with the low category, there were 5 students in the experimental class 1 with an average of $7.80,9$ people in the experimental class 2 with an average of 7.34 , and 12 people in the control class with an average value of 6.32 . The descriptive statistical results of the overall achievement of students' mathematical problem-solving abilities are presented in table 3 below:

Table 3 Descriptive statistics of students' mathematical problem-solving abilities

\begin{tabular}{cccccccccc}
\hline & \multicolumn{3}{c}{ Experiment Class 1 } & \multicolumn{2}{c}{ Experiment Class 2 } & \multicolumn{3}{c}{ Control Class } \\
\hline Ideal score & $\mathrm{N}$ & $\overline{\boldsymbol{x}}$ & SD & $\mathrm{N}$ & $\overline{\boldsymbol{x}}$ & SD & $\mathrm{N}$ & $\overline{\boldsymbol{x}}$ & SD \\
\hline 100 & 20 & 72,57 & & 20 & 69,51 & & 21 & 55,45 & \\
\hline
\end{tabular}

Based on Table 3 above, the average value of students' mathematical problem-solving abilities in the experimental class 1 was 72.57 , the experimental class 2 was 69.51 , and the control class was 55.45. Thus that the average value of students' mathematical problem-solving abilities in the experimental class 1 was higher than the experimental class 2 and the control class. Furthermore, Table 4 shows the average value of students' mathematical problem-solving abilities based on PMA.

Table 4 Descriptive statistics of students' mathematical problem-solving abilities based on PMA

\begin{tabular}{|c|c|c|c|c|c|c|c|c|c|c|c|}
\hline \multirow[t]{2}{*}{ PMA } & \multirow{2}{*}{$\begin{array}{l}\text { Ideal } \\
\text { score }\end{array}$} & \multicolumn{3}{|c|}{ Experiment Class 1} & \multicolumn{3}{|c|}{ Experiment Class 2} & \multicolumn{3}{|c|}{ Control Class } & \multirow{2}{*}{$\begin{array}{c}\text { Total } \\
\bar{x}\end{array}$} \\
\hline & & $\mathrm{N}$ & $\bar{x}$ & SD & $\mathrm{N}$ & $\bar{x}$ & SD & $\mathrm{N}$ & $\bar{x}$ & SD & \\
\hline High & 100 & 6 & & & 4 & & & 2 & & & 78,86 \\
\hline Moderate & & 9 & & & 7 & & & 7 & & & 71,67 \\
\hline Low & & 5 & & & 9 & & & 12 & & & 59,40 \\
\hline
\end{tabular}

Table 4 shows that the average value of students' mathematical problem solving abilities for PMA in the high category was 78.86, for PMA in the medium category was 71.67, and for PMA in the low category was 59.40. Thus it can be concluded that the average score of students' mathematical problem-solving abilities for PMA with the high category is greater than students with moderate and low PMA. Table 5 shows the results of hypothesis testing using the Two-Way Analysis of Variance Test $(\alpha=0.05)$.

Table 5 Hypothesis Test Results of Students' Mathematical Problem Solving Ability by Model and PMA

\begin{tabular}{lccc}
\hline \multicolumn{1}{c}{ Data Group } & Sig. & $\alpha$ & Conclusion \\
\hline RME, PBL, and Conventional Learning Models & 0.000 & 0.05 & Ho accepted \\
PMA High, PMA Medium, and PMA Low & 0.003 & 0.05 & Ho accepted \\
The effect of the interaction between the Learning Model and & 0.000 & 0.05 & Ho was rejected \\
PMA & & & \\
\hline
\end{tabular}

Based on table 5, it is found that the sig value for the learning model of 0.000 is smaller than the value of $\alpha=$ 0.05 , so it is concluded that Ho is accepted. This means that there are differences in the mathematical problemsolving abilities of students who are taught with the RME, PBL and conventional learning models. Judging from the PMA, the sig value is 0.001 less than the value of $\alpha=0.05$. This means that there are differences in students' mathematical problem-solving abilities with the high, medium, and low PMA categories. In terms of the interaction between RME, PBL, and conventional learning models with PMA, the sig value is 0.000 , which is smaller than the value of $\alpha=0.05$. Thus it can be concluded that there is an interaction between the learning model and PMA. Furthermore, a further test is carried out to check what model is the most effective using the Tuckey test. Table 6 shows the results of the Tuckey test.

Table 6 Tukey test results on the Learning Model

\begin{tabular}{cccc}
\hline (I) Class Type & $(\mathrm{J})$ Class Type & $\begin{array}{c}\text { Mean Difference } \\
(\mathrm{I}-\mathrm{N})\end{array}$ & Sig. \\
\hline \multirow{2}{*}{ Experiment 1} & Experiment 2 & $7.4419^{*}$ & 0.000 \\
& Control & $25.9876^{*}$ & 0.000 \\
Experiment 2 & Experiment 1 & $-7.4419^{*}$ & 0.000 \\
& Control & $18.7850^{*}$ & 0.000 \\
Control & Experiment 1 & $-25.9876^{*}$ & 0.000 \\
& Control & $-18.7850^{*}$ & 0.000 \\
\hline
\end{tabular}


Based on Table 6, it was revealed that the mathematical problem-solving abilities of students in the experimental class 1 who were taught using the RME learning model were better than the mathematical problem-solving abilities of the experimental class 2 students who were taught with the PBL model and the mathematical problem-solving abilities of students in the control class who were taught using conventional models. This is because the sig. of 0.000 , which is smaller than the value of $\alpha=0.05$ and the mean difference in the experimental class 1 is 25.9876 greater than the experimental class 2 and control, respectively, namely 18.7850 and 7, 4419. This finding is supported by the results of the study. previously stated that RME had a major effect on students' problem-solving abilities [12], [14].

On the other hand, PMA students also affect students 'mathematical problem solving abilities, where according to the results of data analysis of students' mathematical problem-solving abilities based on PMA, students 'mathematical problem solving abilities with high PMA categories are obtained, better than the students' mathematical problem-solving abilities with moderate and low PMA categories. This is because students in the high PMA category can understand problems, formulate strategies, and complete solving strategies and get solutions to math problems than students with moderate and low PMA categories

\section{CONCLUSION}

The analysis results show that:

a. There are differences in the mathematical problemsolving abilities of students who are taught with the RME, PBL, and conventional learning models where the mathematical problem-solving abilities of students taught with the RME learning model are better than the PBL and conventional learning models.

b. There are differences in the mathematical problemsolving abilities of students with the high, medium, and low PMA categories. Students with high PMA have better mathematical problem-solving abilities than students who have moderate and low PMA.

c. There is an influence of the interaction between the RME, PBL, and conventional learning models with PMA on students' mathematical problem-solving abilities.

\section{REFERENCES}

[1] Bolstad O H, 2020 Secondary teachers' operationalization of mathematical literacy Eur. J. Sci. Math. Educ. 8, 3 p. 115-135

[2] Tamur M, 2017 Pembelajaran Berbasis Software Matematika Sebagai Upaya Mengembangkan Kemampuan Literasi Matematis Siswa in Seminar Nasional Pendidikan Matematika 1, 1 p. 82-92.

[3] Tamur M and Juandi D, 2020 Effectiveness of Constructivism Based Learning Models Against Students Mathematical Creative Thinking Abilities in Indonesia; A Meta-Analysis Study in Mathematics, Science, and Computer Science Education International Seminar, MSCEIS 2019 p. $1-8$.

[4] Nurjanah N Latif B Yuliardi R and Tamur M, 2020 Computer-assisted learning using the Cabri 3D for improving spatial ability and self- regulated learning Heliyon 6, 11 p. e05536.

[5] OECD, 2019, PISA 2018 insights and interpretations.

[6] Susanti N Juandi D and Tamur M, 2020 The Effect of Problem-Based Learning ( PBL ) Model On Mathematical Communication Skills of Junior High School Students - A Meta-Analysis Study JTAM (Jurnal Teor. dan Apl. Mat. 4, 2 p. 145-154.

[7] Tamur M Jehadus E Nendi F Mandur K and Murni $\mathrm{V}, 2020$ Assessing the effectiveness of the contextual teaching and learning model on students' mathematical understanding ability: a metaanalysis study J. Phys. Conf. Ser. 1657, 1 p. 012067.

[8] Freeman-Green S M O'Brien C Wood C L and Hitt S B, 2015 Effects of the SOLVE strategy on the mathematical problem solving skills of secondary students with learning disabilities Learn. Disabil. Res. Pract. 30, 2 p. 76-90.

[9] Tamur M, 2012, Pembelajaran Kooperatif Tipe STAD Berbasis Etnomatematika Sebagai Upaya Meningkatkan Kemampuan Pemahaman Dan Komunikasi Matematis Mahasiswa PGSD: Mengintegrasikan Tarian Caci Ke Dalam Bahan Ajar Di STKIP St Paulus Ruteng-Flores NTT, Universitas Pendidikan Indonesia.

[10] Tamur M Sennen E and Pantaleon K V, 2017 Etnomatematika Daerah Manggarai Flores-Ntt Dalam Tradisi Belis Dan Pengukuran in Seminar Nasional Matematika dan Pendidikan Matematika 5 p. 15-21. 